\title{
O VZŤAHU MEDZI POJMAMI VPLYV A INTERTEXTUALITA V TEÓRII A V INTERPRETÁCII**
}

V štúdii sa venujeme prehl'adu vymedzených teoretických koncepcií, ktoré explikovali pojem vplyv vo vzt’ahu k pojmu intertextualita. V druhej časti štúdie analyzujeme podoby intertextuality $\mathrm{v}$ tvorbe Vít’azoslava Hronca. Ciel'om štúdie je na pozadí konkrétnych príkladov z literatúry vymedzit' postoj k teoretickým východiskám.

Klúčové slová: vplyv, intertextualita, literatúra, Vít’azoslav Hronec

\section{K VZŤAHU MEDZI POJMAMI VPLYV A INTERTEXTUALITA V TEÓRII}

V pátraní po presnom teoretickom vymedzení pojmu vplyv sme sa stretli s protichodnými koncepciami, ktoré vplyv kvalifikujú na jednej strane negatívne, zatial' čo na druhej strane sú názory, ktorými sa vplyv chce vymanit' z negatívnej povesti. Medzi týmito konceptmi sme vypozorovali tri prístupy. Postštrukturalisti explikujú vplyv v kontexte starších literárnovedných koncepcií, najmä v kontexte pozitivizmu a zásadzujú sa za vylúčenie vplyvu z teoretických výskumov a za jeho nahrádzanie pojmom intertextuality. $\mathrm{V}$ druhom prístupe sa pojem vplyv integruje do bádania intertextuálnych relácií. Tretí prístup explikuje vplyv v pozitívnom kontexte a snaží sa poukázat' na dôvody prečo je vplyv dobré zahrnút' do teoretických bádaní aj v súčasnosti. Kedy sa začalo písat' o vplyve?

Marko Juvan $\mathrm{v}$ knihe Intertextualita (Intertekstualnost, rok vydania originálu 2000, rok vydania srbského prekladu, z ktorého citujeme je 2013) podáva stručný prehl'ad chápaní vplyvu od druhej polovice 18. storočia. Juvan píše, že sa

\footnotetext{
*marina.simak@ff.uns.ac.rs

** Práca je individuálnym vystúpením v rámci kolektívneho vedeckého projektu Diskursi manjinskih jezika, književnosti i kulture u jugoistočnoj Evropi, č. 178017, ktorý financuje Ministerstvo osvety, vedy a technologického rozvoja Republiky Srbsko, vedúca riešitel'ka prof. Dr. Anna Makišová.
} 
„[...] pojem vplyvu v literárnej reflexii presadil až v 18. storočí, práve $\mathrm{v}$ tom období, v ktorom klasicistická poetika, antický literárny kánon a imitácia/emulácia upádali. Samotný pojem (z lat. influere „,vtekat' do niečoho“, ,prenikat““, „zakrádat' sa“) bol $\mathrm{v}$ obehu aj pred tým. Pôvodne sa pojem vplyv používal v teológii, medicíne a astrológii a označoval tajomnú, neviditel'nú silu, tvorivú alebo etickú energiu, ktorá z vyšších inštancií (múz, bohov, svätcov) preniká k nižším, slabším bytostiam (l'ud'om) a mení ich vedomosti a vyjadrovanie. [...] Strach, že vplyv je niečo vonkajšie podlamujúce autorovu autenticitu, vkorenený je $\mathrm{v}$ predstavách $\mathrm{o}$ slobodnej, neopakovatel'nej, umeleckej tvorivosti.“(Juvan, 2013: 65, preklad zo srbčiny M.ŠS.S.) ${ }^{1}$

Redefinovanie pojmu vplyv nachádzame v postštrukturalistických koncepciách. Barthes napríklad odlišuje intertext od zdroju a vplyvu. Zdroj a vplyv považoval za následok humanistického individualizmu, popretkávaného ideami o autorstve. Intertext, podl'a Barthesa, má dve dôležité vlastnosti: považuje autora za irelevantného a vnáša kontext družnosti, sociability, na úkor autority autora/tvorcu. Postštrukturalisti vplyv považujú za prejav konzervatívnej koncepcie, ktorá podporuje autority, kánon a hierarchiu. Juvan v knihe Intertextualita (2013) píše, že nová teória intertextuality podstatne zmenila charakter pojmu vplyv. Podl'a nej sa totiž prvotné zdroje stávajú súčast’ou intertextuálnych transformácií. Vd'aka takto chápanej intertextualite je možné preskúmat' širšie pole medziliterárnych a intersemiotických procesov tak medzi textami, ako i širšie vzt’ahy medzi tradíciou a kultúrou. ${ }^{2} \mathrm{Na}$ základe zisteného intertextu je možné identifikovat' a vysvetlit' funkciu daných vzt'ahov a umožnit' nové prístupy $\mathrm{k}$ analyzovanému textu.

Do istej miery v zhode s postštrukturalizmom vysvetluje vplyv americký teoretik Harold Bloom. V sedemdesiatych rokoch 20. storočia Bloom najprv v

\footnotetext{
1 ,[...]pojam uticaja u književnoj refleksiji afirmisao (se) tek u18. veku, dakle baš u razdoblju kada su klasicistička poetika, antički književni kanon i imitacija/emulacija već propadali. Sam izraz (od lat. influere „teći u nešto“, „prodirati“, „prikrasti se“) bio je uopticaju još od ranije. Izvirao je iz metaforike zvezda i pojavljivao se u teologiji, medicini i astrologiji. Označavao je numiozni tok, tajnstvenu, nevidljivu moć, stvaralčku ili etičku energiju koja iz viših, moćnijih instanci (zvezdanih tela, bogova, muza, svetaca) pristiže u duševnost nižih, slabijih bića (ljudi) i menja njihovo znanje ili izražavanje. [...] Strah da uticaj kao nešto spoljašnje podriva autorovu autentičnost ukorenjen je, dakle, u predstavama o slobodnoj, neponovljivoj umetničkoj kreativnosti.“(Juvan, 2013: 65).

${ }^{2}$ Explikáciu pojmu, stručný náčrt dejín intertextuality ako aj prehl'ad teoretických koncepcií intertextuality podáva Ján Jambor v hesle Hyperlexikónu literárnovedných pojmov, ktorý je dostupný na http://hyperlexikon.sav.sk/sk/pojem/zobrazit///intertextualita
} 
knihe U'zkost' z vplyvu (The Anxiety of influence, 1973, do srbčiny preložená pod názvom Antitetička kritika, 1980), potom v knihe Kánon západnej literatúry (The Western Canon, 1994, do češtiny preložená ako Kánon západní literatury, 2000), explikoval vplyv ako dynamický, interliterárny proces. V interliterárnom procese vplyv predstavuje podnet, ktorý treba $\mathrm{v}$ texte prekonat', ktorého sa treba zbavit'. Na rozdiel od Barthesovho chápania intertextuality sa Bloom nezriekol inštancie autora. Tak i intertextualitu chápe ako interpersonálny dialóg, prejavujúci sa cez subjekt, ktorý nemôže byt' „len“ záležitost'ou jazyka. Bloom je známy ako kritik koncepcie „smrti autora“. Písal o štyroch „fantómoch“, ktorí sa riadia „degeneratívnymi procesmi indoktrinácie čitatel’skej praxe“ pričom ako prvého „fantóma“ uvádza Smrt' Autora. Bloom vysvetlil, že druhý „....predstavuje tvrdenie, že vnútorné bytie je fikcia; nasledovným je mienka, že literárne a dramatické postavy sú púhe stopy na stranách. Štvrtým a najnebezpečnejším fantómom je postoj, že jazyk to myslí namiesto nás.“ (Brebanović, 2011: 438, zo srbčiny M.Š.S.). ${ }^{3}$ Proti barthesovským tradíciám Bloom kladie do centra pozornosti básnika, tvoriaceho génia, ktorého reprezentujú jeho tvoriace identity a vymedzenie si priestoru k predchádzajúcim bardom básnického umenia. Aplikovanie uvedenej teórie môže byt' limitujúce pri analýze veršov tematizujúcich samotný jazyk/tvoriaci proces. V Bloomovej koncepcii pojem vplyvu nie je použitý v tradíciách pozitivistického významu, ale ako širšie chápaná intertextualita, prihliadajúca aj na píšuci, respektíve hovoriaci (lyrický) subjekt. Pritom pojem vplyv slúži ako negatívne východisko, ktorého sa talentovaný autor snaží zbavit', integrujúc pritom niektoré literárne a poetické vlastnosti svojich predchodcov do vlastnej tvorby.

Približne $\mathrm{v}$ tom istom období $\mathrm{v}$ sedemdesiatych rokoch 20. storočia vymedzuje vzt’ah k vplyvu aj slovenský komparatista Dionýz Ďurišin. Už v prvej knihe Z dejín a teórie literárnej komparatistiky (1970) vytvoril Ďurišin vlastnú koncepciu literárnej komparatistiky. Explicitne sa postavil proti pojmu vplyv, štúdium vplyvov nazval vplyvológiou a porovnávací výskum literatúr usmernil na bádanie medziliterárnej procesuálnosti. V knihe Teória literárnej komparatistiky (1975) v kapitole Formy medziliterárnej recepcie Durišin píše o podobách medzitextovej nadväznosti, uvádza alúziu, narážku, variáciu, výpožičku, ponášku, plagiát, adaptáciu, preklad, vlastne podoby intertextuality, aj ked' samotný pojem

\footnotetext{
${ }^{3}$, Jedan takav fantom je Smrt Autora, drugi je tvrdnja da je unutrašnje biće fikcija, sledeći je mišljenje da su književni i dramski likovi puki tragovi po stranicama. Četvrti i najpogubniji fantom jeste ubeđenje da jezik misli umesto nas.“ (Brebanović, 2011: 438)
} 
intertextualita neuvádza. Že Ďurišin vlastne uvažoval o podobách intertextuálnych vzt'ahov, aj ked' samotný pojem intertextuality sa v slovenskej literárnej vede ešte nepoužíval ( $\mathrm{v}$ literárnovednom a jazykovom diskurze sa ujal od konca osemdesiatych rokov, o čom sa píše v Hyperlexikóne literárnovedných pojmov) nasvedčuje aj tvrdenie: „Bazírovanie na ,vplyvoch“ sústred’uje pozornost' predovšetkým na pramene nového diela, z ktorých sa obyčajne vyvodzuje novovzniknutý literárny útvar, nezohl'adňujúc pritom jeho funkěnost' a špecifickost'.“(Durišin, 1975: 159, zvýraznila M.Š.S.).

V d’alších teoretických bádaniach hlbšia analýza intertextuálnych procesov priviedla bádatel'ov $\mathrm{k}$ diferencovaniu medzi vedomým (viditel'ným), nevedomým (spontánnym) a latentným intertextuálnym nadväzovaním. V uvedených bádaniach sa do kontextu opät' dostal pojem vplyv.

Kategóriu „neviditel’ného“, „,citel’ného“, alebo tušeného v texte sa zaoberali niekol'kí literárni vedci, použivajúc pritom pojem latencie. ${ }^{4}$ Do súčasného vedeckého diskurzu o textoch latenciu voviedol literárny vedec a filozof Anselm Haverkamp (cit. podl'a Zajac 2016: 23). Zornitza Kazalarska označuje pojem „latentnej intertextuality“ ako „nevedomé, neoznačené a nezamýšl’ané intertextuálne súvislosti medzi textami.“ (Kazalarska, 2012: 189). Z dôvodov „materiálnej“ neúchvatnosti týchto procesov Kazalarska poukazuje, že latentná intertextualita zostáva „mimo dosahu literárnovedných analýz (...) alebo situovaná v staromódnej oblasti výskumu vplyvu, zdrojov, epigónstva.“ (Tamže). Ked’že máme do činenia $\mathrm{s}$,intertextualitou bez intertextu“, na základe čoho vlastne môžeme predpokladat', že ide o intertextualitu - kladieme si otázku spolu s Kazalarskou - respektíve, na základe čoho môžeme tvrdit', že pritom nejde o vplyv, prípadne impulz ? $^{5}$ Pri určovaní latentnej intertextuality má literárny vedec

\footnotetext{
${ }^{4}$ Pojmom latencie v kontexte intertextuality sa zaoberala Zornitza Kazalarska v štúdii „Toto tušenie, ktoré visí vo vzduchu“: Dá sa latentná intertextualita vycítit?, Slovenská literatúra, 185 - 203, na jej štúdiu odkazuje aj Dana Hučková v štúdii o alúzii v slovenskej moderne: Dana Hučková, Kontexty slovenskej moderny, Bratislava, Kalligram). Na niekol'ko Kazalarskej štúdií latencie poukazuje aj Peter Zajac v štúdii Latencie v slovenskej literatúre 19. storočia, Slovenské kargo, Bratislava, Kalligram, 23 - 40. Pojem latencie použila aj Jana Juhásová v monografii Od symbolu k latencii, Ružomberok, Verbum, v kontexte explikácie princípu tajomstva v spirituálnej poézii.

${ }^{5}$ Impulz - zložitejšia podoba interliterárnych relácií - vzt’ahuje sa na konkrétne diela ako aj na širšie celky, ako aj na celé národné literatúry jedného obdobia. Impulz môže iniciovat' celý rad citácií v rozličných literárnych dielach, ale aj rozmanitých spôsobov
} 
k dispozícii prítomnost' „atmosféry“, ktorá sa realizuje prostredníctvom súhry niekol'kých aspektov textu: pocitových priestorov, nálad, ale može byt' aj výsledkom súhry jazykových a štylistických prvkov, ktoré sa podiel'ajú vo vytváraní nálady a atmosféry. Intertextuálny vzt’ah, ktorý v texte „cítit“" sa vlastne stáva konštrukciou čitatel’a, výsledkom je percipientovho „citu“ pre intertextualitu, takže aj identifikácia vzt’ahu latentnej intertextuality je takou, akou ju vidí interpretant, čitatel'.

$\mathrm{Na}$ druhej strane niektorí bádatelia sa snažia revalorizovat' pojem vplyv v snahe vymanit' ho z negatívnej pozitivistickej tradície. Tu však ide o pokus o revalorizáciu vplyvu v širšom zmysle metakomunikačných procesov. Napríklad, komparatistka Angelika Corbineau-Hoffmannová uvažuje o vplyve prostredníctvom prekladu. Podl'a nej vplyv je teoreticky t’ažko uchopitel'ná, no v praxi dôverne známa kategória. Vplyv v komparatistickom zmysle je „zcizující jinakostí“, „alterita“. Vplyv súvisí s inakost’ou, ktorá odbor zároveň „utváří a lomi““ (Corbineau-Hoffmannová, 2008: 73). Oproti teoretikom, ktorí upúšt’ajú od pojmu vplyv, pretože sa nedá vedecky zdôvodnit' - existuje v genéze diela, ale väčšninou zostáva skrytý, komparatistka tvrdí, že sa znevažovanie pojmu vplyv zakladá na omyle, ktorý je vzhl'adom na pozitivistickú teóriu pochopitel'ný, ale sa tým zároveň „s vaničkou vylévá i dítě“ (2008: 74). Práve stopa „iného“ môže podl'a nej odhalit' jedinečnost' diela. Hoffmannová konštatuje, že problematickost' nespočíva v samotnom pojme vplyv, ale v spôsobe, ako sa s ním v texte nakladá. Ked' uvažujeme o vplyve, môžeme sa pýtat': čo autor prevzal, čo zavrhol a prečo.

\section{PODOBY INTERTEXTUÁLNYCH VZŤAHOV V TVORBE VÍŤAZOSLAVA HRONCA}

Vít'azoslav Hronec je autor žijúci v Srbsku, ktorý píše prevažne v slovenskom, ale aj v srbskom jazyku. Z jeho obsiahlej literárnej a esejistickej tvorby na Slovensku vyšlo niekol'ko knižných titulov, ktoré v tamojšej recepcii nadišli niekedy na menšie porozumenie (najmä v období, ked' mu publikačne vyšiel postmoderný experimentálny román Pán vzduchu a králov syn (1993)), nezostali však bez pozitívneho ohlasu. ${ }^{6}$ Hroncove žánrovo rozmanité texty obsahujú

napodobňovania, od preberania postáv a motívov po tvorivé postupy. Uvádzame podla knihy pod názvom: Pregledni rečnik komparatističke terminologije u književnosti i kulturi.

${ }^{6}$ Jedným z ctitel’ov Hroncovej tvorby zo Slovenska bol Viliam Marčok. O akceptovaní Hroncovej poézie Marčok napísal článok, ktorý bol publikovaný vo vojvodinskom časopise 
vlastnosti, ktorými sa vymaňujú z lokálneho kontextu a napájajú do širších medziliterárnych relácií. Medzi tie vlastnosti patrí prítomnost' intertextov, ich funkčné využitie tak v Hroncovom prozaickom, ako aj v poetickom diele, na čo sme sa snažili poukázat' v štúdii Podoby intertextuality v tvorbe Vit'azoslava Hronca (2015) na podklade teoreticko-metodologických východísk chorvátskej autorky Dubravky Oraićovej Tolićovej.

Oraićová Tolićová vníma citovanie nielen ako jednotlivý literárny postup, ale širší ontologický a semiotický princíp. Uvedená teoretička narába s kategóriou „mysleného“ v intertextualite: podla jej vymedzenia každá citačná relácia pozostáva z vlastného textu, 2. cudzieho citovaného textu (citátu, intextu) a 3. cudzieho necitovaného, ale prítomného textu, t. j. podtextu. ${ }^{7}$ (Oraić-Tolić, 1990: 15). Teoretička však neexplikuje kritériá vymedzovania „mysleného textu“. Pri analýze intertextuality v básnickej tvorbe Vít'azoslava Hronca sme najprv vymedzili priame, zjavné citáty a do druhej skupiny sme vyčlenili skryté citáty, čiže motívy, symboly, alúzie, ktoré sme identifikovali v reláciách s inými textami, na ktoré autor neupozornil, alebo poukázal iba sprostredkovane, širším kontextom.

Priame citáty sa v tvorbe Vít'azoslava Hronca vyskytovali bud' ako epigrafy na začiatku básnických zbierok, cyklov básní, jednotlivých veršov, alebo v podobe priamych citátov uvedených voznámkach k zbierke básní. Poznámky k jednotlivým veršom u Hronca pozostávali z citátov veršov, ba aj celých úryvkov z jednotlivých literárnych diel, ktoré autor uviedol na konci zbierky v osobitnom poznámkovom aparáte a vyznačil presne, na ktoré verše sa uvedený citát vzt’ahuje. Tieto citáty v poznámkach sme skúmali v relácii so sémantikou veršov autora. Až po denotovaní významov jednotlivých úryvkov (pri častiach citovaných zo svetovej literatúry sme sa opierali o ich príslušnú literárnovednú interpretáciu) sme mohli porovnat' sémantiku intertextu a určit' funkciu intertextuality: ako sémantický princíp nadväzovania, prehodnocovanie, parodovanie, až po zavrhovanie prototextu. Ked' išlo o určovanie podtextu, teda mysleného textu, bez priameho intertextu vo veršoch V. Hronca - tu sme sa nemohli opriet' o štúdiu Dubravky Oraćovej Tolićovej, ktorá neexplikuje metodológiu jeho identifikácie, iba konštatuje jeho existenciu. V konkrétnom texte V. Hronca sme podtext identifikovali tak, že sme brali do ohl'adu kontext celého textu, v ktorom sme pred

Nový život. Hroncovu postmodernú prózu Marčok zahrnul do výskumov postmodernizmu, publikovaných v knihe V poschodovom labyrinte (2010).

$7 \mathrm{~V}$ danom kontexte je potrebné uviest' dištinkciu medzi pojmami podtext a prototext: podtext je myslený cudzí text, prototext je reálny cudzí text. 
tým určili funkciu priamych citátov. Napríklad pri básni Modlitba I. z Hroncovej tretej zbierky Hranica (1981) sme identifikovali podtext paralelným čítaním Hroncovej básne a Eposu o Gilgamešovi, pričom sme siahli po tej časti Eposu o Gilgamešovi, z ktorej bol v zbierke už uvedený priamy citát ako motto. ${ }^{8}$ Pri paralelnom čítaní Hroncovej básne a Eposu o Gilgamešovi, zistili sme množstvo „prepisov“ aj z iných častí skladby. Napríklad v motívoch dažd’u/krupobytia, potopy/umierania, náreku/plaču v básni Modlitba I. Verše sa začínajú obrazom búrky, „semenným krupobitím“ (Hronec, 1981: 12), ktoré možno interpretovat’ ako tvorivé vnuknutie. „Semenné krupobitie“ sa prirovnáva k božským bleskom a k náreku starien, čo môže byt' plač pri umierajúcom, respektíve pri hrobe. V jedenástej tabul'ke Eposu o Gilgamešovi sa zobrazuje začiatok potopy: „Ked’ ráno koláče a večer pšenica ako dážd’ padali, / vyzeral som na nebi búrlivé mračno / a prišlo mračno, na ktoré pohl'ad bol strašný“ (Epos o Gilgamešovi, 1975: 148). V pokračovaní eposu sa uvádza, že pri pohl'ade na potopu „bohyňa s krásnym hlasom, Ištar, nariekala:“ (1975: 149). Mytologický podtext Modlitby I. čoskoro vystriedali biblické symboly chleba, krvi a márnotratného syna. Kontext biblických motívov spolu s názvom básne sme vnímali vo význame kultúrno-civilizačného rámca, v ktorom sa vyskytuje kontext existencie Hroncovho subjektu. Spoločné motívy sme interpretovali ako obrazy symbolickej potopy, ktorej predobraz sa nachádza v Epose o Gilgamešovi a ktoré predznamenávajú (v mytológii kozmický, v reálnom živote osudový) predel v živote subjektu, situáciu pred vstupom do novej životnej etapy. Teda v Hroncovej básni identifikujeme jednotlivé motívy ako intertexty, hoci by teoreticky tie motívy mohli byt' aj náhodné. Motívy usúvzt’ažňujeme do sémantických súvislostí na pozadí podtextu, ktorý sme identifikovali porovnávaním s textom, ktorý bol priamo citovaný v podobe motta. Atmosféru blížiacej sa potopy v novom kontexte utvorili podobné motívy dvoch rozličných textov v korelácii. Modlitbu I. možno čítat' i ako ret’az obrazov, ktorý zastupuje zrod básne, od začiatočnej chvíle vnuknutia (Múzou, Bohyňou, v intertextovej súvislosti aj textom) po samotný čin dokončenia básne: „Prinášam ti / Č́re slovo / Sna." (Hronec, 1981: 13). V konečnom dôsledku báseň Modlitba I. spolu s identifikovaným mysleným podtextom možno interpretovat' ako obrazmi vyjadrenú časovú simultánnost', zatial' čo z teoretického aspektu ide o nepriamu (skrytú) intertextualitu, umožňujúcu aby sa jednotlivé obrazy prevrstvovali, epochy spájali do záznamu tvorivého procesu a vzniku poézie. Z príkladu vyplýva, že pri určovaní podtextu (mysleného textu, z ktorého autor cituje) a funkcie skrytej

\footnotetext{
${ }^{8}$ Motto bolo prebraté zo štvrtej tabul'ky Eposu o Gilgamešovi.
} 
intertextuality čitatel' sa môže spoliehat' jednak na „cit“, no v konkrétnom prípade Hroncovej tvorby aj na kontext celkovej autorovej tvorby, resp. kontext predtým identifikovanej intertextuality.

Iný príklad potenciálnej latentnej intertextuality v poetike identifikujeme $\mathrm{v}$ Hroncových veršoch z druhej polovice šest'desiatych rokov 20. storočia. ${ }^{9}$ V danom období je pre poetiku Hroncových básní príznačná svojrázna hudobnost', realizujúca sa prostredníctvom zvukovo-štylistických opakovaní ale aj v motívoch hudby. Uvedená „hudobnost “" Hroncových veršov by sme mohli interpretovat' niekol'kými spôsobmi: ako vyrovnávanie sa s „'ubozvučnost'ou“ slovenskej básnickej tradície, vhl’adom na intertextuálne súvislosti v zbierke Sol', ale piesok (1971) ako vzt'ah $\mathrm{k}$ poetike slovenských senzualistov (Stacha), ale aj imagistov, ktorých niekol'kokrát priamo a utajene cituje. V štúdii (2015) sme v Hroncových básňach uvedeného obdobia identifikovali priame intertextuálne väzby s veršami T. S. Eliota, E. Pounda. ${ }^{10}$ Zatil' čo Eliota a Pounda Hronec priamo cituje, denníkové záznamy autora v knihe Remeslo byt' (2011) ${ }^{11}$ svedčia o čítaní poézie iných imagistov, ktorých poetiku si Hronec osvojoval. V Hroncovom denníkovom zázname z roku 1965 existuje zápis, že si Eliotovu báseň Lúbostná pieseň J. Alfreda Prufrocka (The Love Song of J. Alfred Prufrock) naštudoval ešte v roku $1963 .{ }^{12} \mathrm{~V}$ názve básne Lúbostná pieseň... sa naráža na špecifickú hudobnost' verša. Hudobnost' bola v základoch veršovania (v podstate odklonom od akýchkol'vek verzologických zásad) imagistickej básnickej školy. Zaujímavé je, že hudobný motív obsahuje i prvá Hroncova báseň uverejnená v Novom živote, sonet Gitara, hoci v tomto prípade ešte nešlo o tvorbu inšpirovanú Eliotom. O vedomom využití hudobného motívu v titule však možno uvažovat' v prípade prvej uverejnenej poviedky, ktorej názov, Ocelová

\footnotetext{
${ }^{9}$ Básne z druhej polovice šest'desiatych rokov 20. storočia boli zaradené do prvej Hroncovej zbierky Hviezdy, pobrežie (1969) a do druhej zbierky Sol', ale piesok (1971).

${ }^{10}$ Bližšie v Podoby intertextuality v tvorbe Vit'azoslava Hronca (2015).

11 Vít’azoslav Hronec uverejnil svoje denníkové záznamy pod pseudonymom vlastného literárneho hrdinu Vladimíra Lutrova najprv $\mathrm{v}$ troch osobitných knihách (Stretnutie $s$ Minotaurom (1997), Nebo nad Helespontom (2003), Lemnos, Lemnos (2009)) a potom všetky tri knihy zahrnul do siedmeho zväzku výberu z diela pod názvom Remeslo byt' 1 (2011).

12 „Ked’ som predvlani na jeseň (záznam je datovaný 10. januárom 1965, poznámka M. Š. S.) začal, kus po kuse, pomaly objavovat' mesto, Gorjanov preklad jeho (Eliotovej, poznámka M. Š. S.) Lúbostnej piesne J. Alfreda Prufrocka (The Love Song of J. Alfred Prufrock) mal som už naštudovaný takpovediac do podrobností.“(Lutrov, 2011: 15).
} 
gitara a pohár vína (1965), je prekladom názvu piesne Paula Anku A stelle guitar and a glass of wine. V štúdii (2015) sme sa snažili argumetnovat', že Hroncove denníky spíňajú funkciu komentára vlastnej tvorby: poetiky, inšpirácie a kontextu, v ktorom tvoril, čím sme ich zaradili $\mathrm{k}$ autoreferenčnej intertextualite. ${ }^{13}$ Širší kontext intertextuality $\mathrm{v}$ Hroncovej tvorbe a porovnanie funkcie hudobnosti u imagistov s funkciou potenciálnej hudobnosti, ktorá rozrušuje „l'ubozvučnost"“ vo veršoch Hronca ukazujú na latentnú prítomnost' poetiky imagistov v básňach $\mathrm{V}$. Hronca. Podobne ako imagisti účtovali s predchádzajúcim verzologickým systémom, u Hronca zvukovú a rytmickú stránku verša rozrušuje napríklad aliteračné a paronomazické opakovanie, ktoré rytmom upriamujú pozornost' na intelektuálny obsah. ${ }^{14}$ Hroncove poetické ,zvuky“ bublania, šumy a zvony akoby mali za ciel' prispiet' $\mathrm{k}$,otvoreniu“ zmyslov voči novému poznaniu a asociujú skôr šamanistický rituál než l'ubozvučnú, harmonizačnú pieseň. Môže to byt' asociácia na tú rituálnost' a obradnost' piesne, ktorá je $\mathrm{v}$ základoch lyriky a tragédie, či ešte širšie, v základoch orálnej kultúry veštenia a predpovedania budúcnosti. Uvedené môže poukazovat', že sa poetika imagismu, ale aj rituálna kultúra latentne podiel’a v sémantických a poetologických procesoch Hroncových básní. Aj v tomto prípade pri explikácii kategórie latentnej poetiky sme si pomohli explicitným medzitextovým nadväzovaním v Hroncovej básnickej tvorbe a porovnaním funkcie poetiky hudobnosti verša u Eliota, respektíve imagismu a v Hroncovom texte. Otázka, ako identifikovat' latentnú intertextualitu v tých textoch, ktoré neobsahujú priame citačné zdroje, zostáva však nad’alej otvorená.

V Hroncovej tvorbe nachádzame aj príklad toho, čo Kazalarska vyčleňuje ako „pocitovú prítomnost'“ súvzt’ažností, ktoré sú t’ažko doložitel'né, za ktoré autorka navrhuje teoretický pojem ,intertextuálna atmosféra“. Atmosféry môžu byt' myslené, transsubjektívne komunikované a citované (Kazalarska, 2012: 196), pričom pojem vychádza z charakteristických znakov, ako sú priestorovost',

13 „Denníkové záznamy zjednotené do knihy Remeslo byt' 1 predstavujú d'alší zorný uhol nazerania na vznik básnického sveta a na skutočnost'. Stávajú sa d’alším odrazom (komentárom) nielen poézie, ale aj skutočnosti (života) ich autora (Vít’azoslava Hronca), tým pádom aj predobrazom novej reflexie, ktorú predstavuje prozaický svet (V. Lutrova).“ (Šimáková Speváková, 2015: 91).

${ }^{14} \mathrm{Na}$ ilustráciu uvádzame úryvok z básne Prečo uspávanka, ked’ úsvit: „Šarlátová bublina hudby / a pohyb;“ (1971: 11); „,v tom medzipriestore / medzi dvoma tepmi, nad ránom,“; „kým prievan brieždenia“ (1971: 11); výskyt slovies „Zvonit““, „šumiet‘“ v básni sú tiež zmyslovo evokatívne. 
atmosférickost', kvázi-objektivita a produkovatel'nost'. V rámcoch daného priestoru v texte sa evokujú latentne prítomné odkazy minulého - môže íst' o prítomnost' histórie intímy, vlastnej rodiny, ale aj človečenstva všeobecne. V Hroncovej postmodernistickej poviedke Trinást' veršov identifikujeme prítomnost' intertextuálnej atmosféry:

Privrel som viečka a ocitol som sa v tme, kde už nič nevedelo hovorit'. Ale len čo som ich znova otvoril, stroj na stole sa začal núkat' mojim zmyslom nie ako jediný predmet, ale ako súhrn súčiastok, pričom som vokamihu zaregistroval celú ich históriu, celý proces výroby každej z nich, ale nie v slede, teda každú osobitne, lež všetky odrazu, ale predsa každú osve, až po tú chvílu, ked' som pred dvadsiatimi dvomi rokmi kupoval tento stroj v papiernictve na Zmajovej ulici. (...) videl som tisice drevorubačov, robotnikov spracúvajúcich drevo, robotnikov v papierňach, šférov, spisovatelov, redaktorov, lektorov, korektorov, sadzačov, typografov, predavačov a iných l'udi, ktorí sa zúčastnili na výrobe týchto kníh okolo mña, videl som ich všetkých odrazu, ale predsa každého osve a celkom jasne, videl som všetko, čo sa dialo s každým predmetom v tejto izbe od začiatku sveta až do tejto chvíle, videl som to, no i tak mi to neprekážalo, aby som aj d'alej celkom normálne rozmýšl'al, akoby sa nič, celkom nič nestalo ani vo mne, ani vôkol mňa... (Hronec, 2000: $82-83$ ).

V uvedenom úryvku identifikujeme Kazalarskou definovaný cit pre latentnú prítomnost' cudzích osudov, ktorý je priamo spojený s intenzívnym precítením priestorovej blízkosti neprítomného. Na rozdiel od Kazalarskej príkladu z poézie I. Blatného, v ktorom si autorka kladie otázku, či je jazykové vytvorenie atmosfér priamo viazané alebo neoddelitel'ne späté s empirickou subjektivitou autora, pri Hroncovom príklade ide o prežívanie literárnej postavy z poviedky Trinást’ veršov, básnika prepisujúceho vlastné verše. Preživajúci subjekt sa dostáva do relácie s postmodernou problematikou prehodnocovania autorstva. Evokácia minulosti prostredníctvom intertextuálnej atmosféry u Hronca sa stáva súčastou postmoderného prehodnocovania úlohy minulosti v tvorivom procese, ktorý ju v súčasnej dobe (tú minulost') zároveň obsahuje, ale aj problematizuje. (Hronec, 2000: 83).

Na pozadí štúdie Kazalarskej, ktorá o latencii uvažuje ako o „historicky dominantnom pocite polovice 20. storočia“ (Kazalarska, 2012: 201) a príkladov z tvorby V. Hronca môžeme d'alej uvažovat' o latencii ako pocite, ktorý pretrváva aj v druhej polovici 20. storočia (šest'desiate, sedemdesiate, osemdesiate roky). S tým v súvislosti aj latentná intertextualita získava svoje obdoby (latentný podtext, latentná poetika). 


\section{ZÁVEROM}

Súčasná literárna veda sa $\mathrm{v}$ úplnosti nezrieka pojmov $\mathrm{z}$ minulosti a prehodnocuje koncepcie a pojmy, akým je napríklad aj vplyv. Vplyv môžeme explikovat' ako dedičstvo obsiahnuté $\mathrm{v}$ súčasnosti, voči ktorému sa vymedzujú nové postoje a na pozadí ktorých vznikajú nové teoretické kategórie. Pojem vplyv môže rezonovat' v súčasnej teórii v súlade s tým, čo tvrdila aj Hoffmannová, na spôsob, ako sa s pojmom vplyv v texte nakladá. Vplyv môžeme brat' ako jedno z východísk, z ktorého sa rozbiehajú nové bádania a formujú nové teoretické vzt'ahy, ako napríklad prostredníctvom pojmov latentná intertextualita, intertextuálna atmosféra. V konečnom dôsledku, tieto poznania nás pri interpretácii môžu zaviest' len $\mathrm{k}$ hlbšiemu poznaniu literárneho diela.

\section{Marína Šimáková Speváková \\ ON THE RELATIONSHIP BETWEEN THE TERMS 'INFLUENCE' AND 'INTERTEXTUALITY' IN THEORY AND INTERPRETATION}

\section{Summary}

In this study we focus on those theoretical concepts that explain the concept of influence in relation to intertextuality. In post-structuralist conceptions, the notion of influence is considered part of the positivist past. On the other hand, some contemporary comparative conceptions (A. Corbineau-Hoffmann) actualize the notion of influence in broader metacommunication processes. In relation to the concepts of intertextuality and influence there is also the concept of latent intertextuality, which, in Kazalarska's opinion, is perhaps a form of influence since it is objectively "elusive" just like the concept of influence. We look at these theoretical concepts through an analysis of the forms of intertextuality in the works of V. Hronec. We find a possible explanation of latent intertextuality in the wider context of the works of $\mathrm{V}$. Hronec by comparing it with parts of the text in which intertextuality is not hidden. We conclude that the notion of influence is actualized in contemporary theoretical thought as a legacy, in relation to which new theoretical considerations are formed and new concepts are defined that enable a deeper knowledge of a literary work.

Key words: influence, intertextuality, literature, Vít’azoslav Hronec. 
O ODNOSU IZMEĐU POJMOVA UTICAJ I INTERTEKSTUALNOST U TEORIJI I INTERPRETACIJI

\begin{abstract}
Rezime
U studiji posvećujemo pažnju teorijskim koncepcijama u kojima se objašnjava pojam uticaja u relaciji sa pojmom intertekstualnost. U poststrukturalističkim koncepcijama, pojam uticaja se smatra delom pozitivističke prošlosti. S druge strane u nekim savremenim komparatističkim koncepcijama (A. Corbineau-Hoffman) ovaj pojam se aktualizuje u kontekstu širih metakomunikacijskih procesa. U relaciji sa pojmovima intertekstualnost i uticaj nalazimo pojam latentne intertekstualnosti, koji po mišljenju Z. Kazalarske, može da predstavlja vid uticaja, budući da je, kao i sam uticaj, objektivno „neuhvatljiv“. Pomenute teorijske pojmove posmatramo kroz oblike intertekstualnosti u delu V. Hronjeca. Kod latentne intertekstualnosti u delu V. Hronjeca nalazimo njegovo moguće objašnjenje u širem kontekstu Hronjecovog teksta, upoređivanjem sa delovima teksta u kojima intertekstualnost nije skrivena. Zaključujemo, da se pojam uticaja aktualizuje u savremenoj teorijskoj misli kao nasleđe, u odnosu na koje se formiraju nova teorijska razmatranja, definišu novi pojmovi koji omogućavaju dublje poznavanje književnog dela.
\end{abstract}

Ključne reči: uticaj, intertekstualnost, književnost, Vićazoslav Hronjec

\title{
PRAMENE
}

Epos o Gilgamešovi. (1975). Bratislava: Tatran.

Hronec, V. (1981). Hranica. Nový Sad: Obzor.

Hronec, V. (1971). Sol', ale piesok. Nový Sad: Obzor.

Hronec, V. (2000). Amarna 1. Beograd, Báčsky Petrovec: Zavod za udžbenike i nastavna sredstva, Kultúra.

Lutrov, V. (2011). Remeslo byt’ 1. Denník V. A. Hronca 1964-1984. Stará Pazova: Art centrum Chlieb a hry.

\section{LITERATÚRA}

Blum, H. (1980). Antitetička kritika. Beograd: Slovo ljubve.

Brebanović, P. (2011). Antitetički kanon Harolda Blooma. Beograd: Fabrika knjiga. Corbineau-Hoffmannová, A. (2008). Úvod do komparatistiky (Einführung in die Komparatistik, 2000). Prel. V. Jičínská. Praha: Akropolis.

Hyperlexikónu literárnovedných pojmov. http://hyperlexikon.sav.sk/ Preuzeto 29.09.2019.

Hučková, D. (2014). Kontexty slovenskej moderny. Bratislava: Kalligram, Ústav slovenskej literatúry.

Juvan, M. (2013). Intertekstualnost (Intertekstualnost, 2000). Prev. B. Stojanović Pantović. Novi Sad: Akademska knjiga. 
Kazalarska, Z. (2012). „Toto tušenie, ktoré visí vo vzduchu“: Dá sa latentná intertextualita vycítit? Slovenská literatúra, LIX, 185-203.

Oraić Tolić, D. (1990). Teorija citatnosti. Zagreb: Grafički zavod Hrvatske.

Pregledni rečnik komparatističke terminologije u književnosti i kulturi. (2011). Urednici: Bojana Stojanović Pantović, Miodrag Radović, Vladimir Gvozden. 1. izdanje. Novi Sad: Akademska knjiga.

Šimáková Speváková, M. (2015). Podoby intertextuality v tvorbe Vit'azoslava Hronca. Novi Sad: Fondacija akademika Bogumila Hrabaka za publikovanje doktorskih disertacija, Vojvodjanska akademija nauka i umetnosti.

Zajac, P.(2016). Slovenské kargo. Bratislava: Kalligram. 